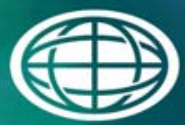

Savannah River

National Laboratory "m

OPERATED BY SAVANNAH RIVER NUCLEAR SOLUTIONS

Sludge Batch 9 (SB9) Acceptance

Evaluation: Radionuclide Concentrations

in Tank 51 SB9 Qualification Sample

Prepared at SRNL

C. J. Bannochie

D. P. DiPrete

J. M. Pareizs

February 2016

SRNL-ST1-2016-00026, Revision 0 


\section{DISCLAIMER}

This work was prepared under an agreement with and funded by the U.S. Government. Neither the U.S. Government or its employees, nor any of its contractors, subcontractors or their employees, makes any express or implied:

1. warranty or assumes any legal liability for the accuracy, completeness, or for the use or results of such use of any information, product, or process disclosed; or

2. representation that such use or results of such use would not infringe privately owned rights; or

3. endorsement or recommendation of any specifically identified commercial product, process, or service.

Any views and opinions of authors expressed in this work do not necessarily state or reflect those of the United States Government, or its contractors, or subcontractors.

\section{Printed in the United States of America \\ Prepared for U.S. Department of Energy}


Keywords: $D W P F, S B 9$, Qualification, Radionuclide

Retention: Permanent

\title{
Sludge Batch 9 (SB9) Acceptance Evaluation: Radionuclide Concentrations in Tank 51 SB9 Qualification Sample Prepared at SRNL
}

\author{
C. J. Bannochie \\ D. P. DiPrete \\ J. M. Pareizs
}

February 2016

Prepared for the U.S. Department of Energy under

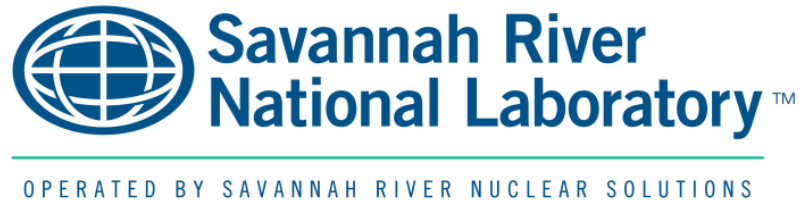
contract number DE-AC09-08SR22470. 


\section{REVIEWS AND APPROVALS}

\section{AUTHORS:}

TECHNICAL REVIEW:

C. L. Crawford, Engineering Process Development, Reviewed per E7 2.60

APPROVAL:

F. M. Pennebaker, Manager

Date

Processing Technology Programs

D. E. Dooley, Director

Date

Environmental \& Chemical Process Technology Research Programs

\section{E. J. Freed, Manager}

Date DWPF \& Saltstone Facility Engineering

R. E. Edwards, Manager

Date

Nuclear Safety and Engineering Integration 


\section{PREFACE OR ACKNOWLEDGEMENTS}

The authors would like to thank Chuck Coleman (Analytical Development) for assistance with the aqua regia and alkali fusion digestions, and Mira Malek and Ceci DiPrete (Analytical Development) for assistance with the radionuclide measurements. We also acknowledge the Savannah River National Laboratory (SRNL) Shielded Cells technicians and management whose efforts facilitated the timely processing of this sludge sample. 


\section{EXECUTIVE SUMMARY}

Presented in this report are radionuclide concentrations required as part of the program of qualifying Sludge Batch 9 (SB9) for processing in the Defense Waste Processing Facility (DWPF). The SB9 material is currently in Tank 51 and has been washed and prepared for transfer to Tank 40. The acceptance evaluation needs to be completed prior to the transfer of the material in Tank 51 to Tank 40. The sludge slurry in Tank 40 has already been qualified for DWPF processing and is currently being processed as Sludge Batch 8 (SB8). ${ }^{\mathrm{i}}$ The radionuclide concentrations were measured or estimated in the Tank 51 SB9 Washed Qualification Sample prepared at Savannah River National Laboratory (SRNL). This sample was prepared from a three liter sample of Tank 51 sludge slurry (HTF-51-15-81) taken on July 23, 2015. The sample was delivered to SRNL where it was initially characterized in the Shielded Cells. ${ }^{\text {ii }}$ Under the direction of Savannah River Remediation (SRR) it was then adjusted per the Tank Farm washing strategy as of October 20, 2015. ${ }^{\text {iii }}$ This final slurry now has a composition ${ }^{\text {iv }}$ expected to be similar to that of the slurry in Tank 51 after final preparations have been made for transfer of that slurry to Tank 40.

Determining the radionuclide concentrations in this Tank 51 SB9 Qualification Sample is part of the work requested in Technical Task Request (TTR) No. U-TTR-S-00009, Rev. 1. ${ }^{\mathrm{v}}$ The work with this qualification sample is covered by a Task Technical and Quality Assurance Plan (TTQAP). ${ }^{\text {vi }}$ The radionuclides included in this report are needed for the DWPF Radiological Program Evaluation, the DWPF Waste Acceptance Criteria (WAC) Evaluation, and the DWPF Solid Waste Characterization Program (TTR Task I.B.1). The sample is the same as that on which the chemical composition was reported. $^{\text {iv }}$ Radionuclides required to meet the Waste Acceptance Product Specifications (WAPS) (TTR Task III.2) will be measured at a later date after the slurry from Tank 51 has been transferred to Tank 40. Then a sample of the as-processed SB9 will be taken from Tank 40 and transferred to SRNL for measurement of these radionuclides.

The results presented in this report are those necessary for DWPF to assess if SB9 meets the requirements for the DWPF Radiological Program Evaluation, the DWPF WAC evaluation, and the DWPF Solid Waste Characterization Program. Concentrations are given for thirty-seven radionuclides along with total alpha and beta activity. Values for total gamma and total gamma plus beta activities are also calculated.

Results also indicate that $91 \%$ of the Tc-99 that could have been in this sludge batch was removed by chemical processing steps in the SRS Canyons or Tank Farm - it is typical for Tc-99 to partition to the salt phase of the waste. The I-129 found in the sludge was likely retained as a nonvolatile mercury species.

i. $\quad$ Pareizs, J. M. and Crawford, C. L., Sludge Washing and Demonstration of the DWPF Flowsheet in the SRNL Shielded Cells for Sludge Batch 8 Qualification, SRNL-STI-2013-00116, Savannah River National Laboratory, Aiken, SC 29808 (2013).

ii. $\quad$ Pareizs, J. M., Characterization of the As-Received Sludge Batch 9 Qualification Sample (HTF-51-15-81), SRNL-STI-201500442, Savannah River National Laboratory, Aiken, SC 29808 (2015).

iii. Gillam, J. M., Sludge Batch 9 Washing Spreadsheet: SB9_102015.xlsm, Savannah River Remediation, Aiken, SC 29808 (2015).

iv. Pareizs, J. M., Characterization of the SRNL-Washed Tank 51 Sludge Batch 9 Qualification Sample, SRNL-STI-201500693, Savannah River National Laboratory, Aiken, SC 29808 (2016).

v. Samadi-Dezfouli, A., Technical Task Request: Sludge Batch 9 Qualification, Confirmatory, and Waste Acceptance Product Specification Samples, U-TTR-S-00009, Rev. 1, Savannah River Site, Aiken, SC 29808 (2015).

vi. Pareizs, J. M., Task Technical and Quality Assurance Plan for Sludge Batch 9 Qualification, Confirmatory, and Waste Acceptance Product Specification Samples, SRNL-RP-2015-00120, Rev. 1, Savannah River National Laboratory, Aiken, SC 29808 (2015). 


\section{TABLE OF CONTENTS}

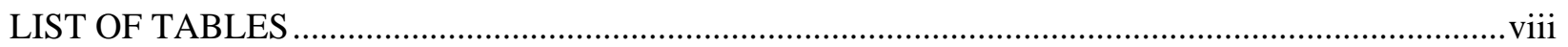

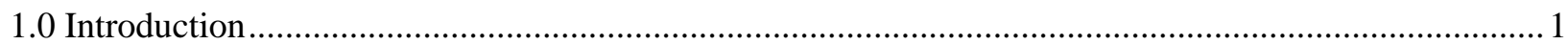

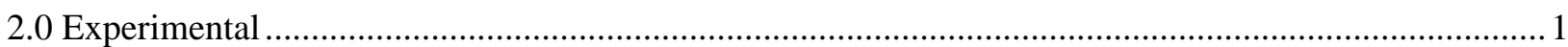

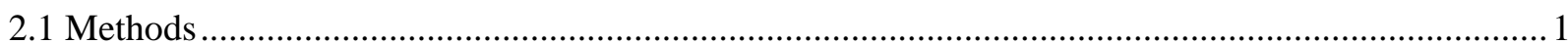

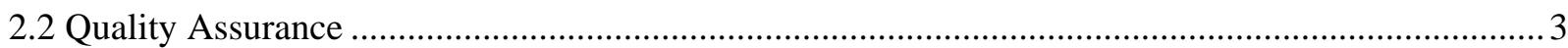

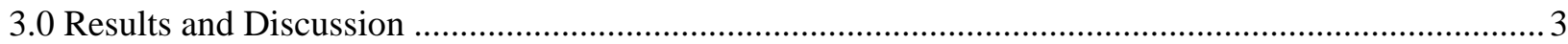

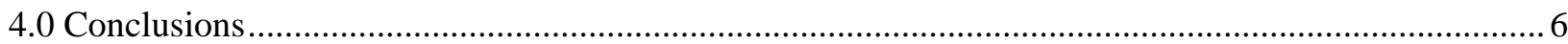

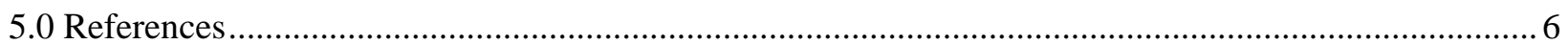




\section{LIST OF TABLES}

Table 2-1. Weight Percent Solids and Density for Washed Tank 51 SB9 Samples .................................. 2

Table 3-1. Concentrations of Radionuclides in the Tank 51 SB9 Qualification Sample........................... 5

Table 3-2 Replicate Activities of Fissile Radionuclides for the SB9 Qualification Sample in $\mu \mathrm{Ci} / \mathrm{g}$ of

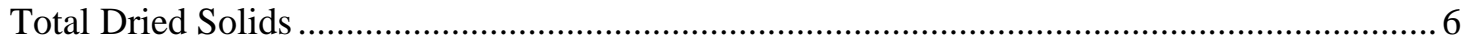




\section{LIST OF ABBREVIATIONS}

$\begin{array}{ll}\text { AD } & \text { Analytical Development } \\ \text { Ci } & \text { Curie } \\ \text { DOE } & \text { Department of Energy } \\ \text { DWPF } & \text { Defense Waste Processing Facility } \\ \text { DSFE } & \text { DWPF/Saltstone Facility Engineering } \\ \text { FYSF } & \text { Fission Yield Scaling Factor } \\ \text { g } & \text { gram } \\ \text { HLW } & \text { High Level Waste } \\ \text { HTO } & \text { tritiated water } \\ \text { IAEA } & \text { International Atomic Energy Agency } \\ \text { ICP-MS } & \text { Inductively Coupled Plasma - Mass Spectrometry } \\ \text { L } & \text { liter } \\ \mu \text { Ci } & \text { micro-Curie } \\ \text { \%RSD } & \text { Percent Relative Standard Deviation } \\ \text { SB } & \text { Sludge Batch } \\ \text { SpA } & \text { Specific Activity (Ci/g) } \\ \text { SRNL } & \text { Savannah River National Laboratory } \\ \text { SRR } & \text { Savannah River Remediation } \\ \text { SRS } & \text { Savannah River Site } \\ \mathrm{t}_{1 / 2} & \text { half-life } \\ \text { TTQAP } & \text { Task Technical and Quality Assurance Plan } \\ \text { TTR } & \text { Technical Task Request } \\ \text { WAC } & \text { Waste Acceptance Criteria } \\ \text { WAPS } & \text { Waste Acceptance Product Specifications } \\ \text { WCS } & \text { Waste Characterization System } \\ \text { Wt\% } & \text { Weight Percent } \\ & \end{array}$




\subsection{Introduction}

Presented in this report are radionuclide concentrations required as part of the program of qualifying Sludge Batch 9 (SB9) for processing in the Defense Waste Processing Facility (DWPF). The SB9 material is currently in Tank 51 and has been washed and prepared for transfer to Tank 40 . The acceptance evaluation needs to be completed prior to the transfer of the material in Tank 51 to Tank 40. The sludge slurry in Tank 40 has already been qualified for DWPF processing and is currently being processed as Sludge Batch 8 (SB8). ${ }^{1}$ The radionuclide concentrations were measured or estimated in the washed Tank 51 SB9 Qualification Sample prepared at Savannah River National Laboratory (SRNL). This sample was prepared from a three liter sample of Tank 51 sludge slurry (HTF-51-15-81) taken on July 23, 2015. The sample was delivered to SRNL where it was initially characterized in the Shielded Cells. ${ }^{2}$ Under the direction of Savannah River Remediation (SRR) it was then modified per the Tank Farm washing strategy as of October 20, 2015. ${ }^{3}$ This final slurry now has a composition ${ }^{4}$ expected to be similar to that of the slurry in Tank 51 after final preparations have been made for transfer of that slurry to Tank 40.

Determining the radionuclide concentrations in this Tank 51 SB9 Qualification Sample is part of the work requested in Technical Task Request (TTR) No. U-TTR-S-00009, Rev. 1. ${ }^{5}$ The work with this qualification sample is covered by a Task Technical and Quality Assurance Plan (TTQAP). ${ }^{6}$ The radionuclides included in this report are needed for the DWPF Radiological Program Evaluation, the DWPF Waste Acceptance Criteria (WAC) Evaluation, and the DWPF Solid Waste Characterization Program (TTR Task I.B.1). The sample is the same as that on which the chemical composition was reported. ${ }^{4}$ Radionuclides required to meet the Waste Acceptance Product Specifications (TTR Task III.2) will be measured at a later date after the slurry from Tank 51 has been transferred to Tank 40. Then a sample of the as-processed SB9 will be taken from Tank 40 and transferred to SRNL for measurement of these radionuclides.

\subsection{Experimental}

\subsection{Methods}

Three wash/decant cycles were conducted at SRNL to mimic the projected washing in Tank $51 .^{3}$ After the three washes and decants, an aliquot of the 3-L Tank 51 sample was taken for analyses. The $\sim 400 \mathrm{~mL}$ aliquot taken for the radionuclide measurements and other characterization was called "SB9 TK 51 Washed Analytical Subsample” and is the SB9 Qualification Sample prepared at SRNL prior to blending with Tank 40 material.

Data presented in this report represents the measured or estimated radionuclide concentrations obtained from several standard analytical methods performed by SRNL Analytical Development (AD) personnel. These methods were performed on solutions resulting from the dissolutions of the slurry samples. The dissolution methods were an alkali fusion ${ }^{7}$ and an aqua regia digestion. ${ }^{8}$ Two additional preparation schemes were performed to obtain the Am/Cm data and the I-129 data: these methods have been described previously. ${ }^{9}$

Table 2-1 presents the weight percent solids and density measurements for the washed qualification sample prepared at SRNL, ${ }^{4}$ both sludge slurry (henceforth referred to as "slurry") and supernate. Total and insoluble solids are given only on a slurry basis. 
Table 2-1. Weight Percent Solids and Density for Washed Tank 51 SB9 Samples

\begin{tabular}{ccccc}
\hline Sample Name & $\begin{array}{c}\text { Wt\% Total } \\
\text { Solids } \\
{[\% \text { RSD]* }}\end{array}$ & $\begin{array}{c}\text { Wt\% } \\
\text { Soluble } \\
\text { Solids } \\
\text { [\%RSD]* }\end{array}$ & $\begin{array}{c}\text { Wt\% } \\
\text { Insoluble } \\
\text { Solids } \\
\text { [\%RSD]* }\end{array}$ & $\begin{array}{c}\text { Density } \\
\text { (g/mL) } \\
\text { [\%RSD]* }\end{array}$ \\
\hline Slurry & $19.59[0.6]$ & $4.98[\mathrm{~N} / \mathrm{A}]$ & $14.61[\mathrm{~N} / \mathrm{A}]$ & $1.15[4.9]$ \\
Supernate & $\mathrm{NA}$ & $5.83[0.7]$ & $\mathrm{NA}$ & $1.04[1.2]$ \\
\hline
\end{tabular}

* RSD $\equiv$ relative standard deviation; \%RSD is defined as the standard deviation of an array, divided by the average of the array, expressed in percent terms.

$\mathrm{N} / \mathrm{A} \equiv$ not applicable as result is calculated

$\mathrm{NA} \equiv$ not applicable to supernate sample

The experimental procedures for specific radionuclides are discussed below. The concentration of tritium in the supernate of the sludge slurry was not determined by using a sample of the supernate that had been separated from the insoluble solids by filtration, as was done for Sludge Batch (SB6). Instead, the tritium concentration in the slurry was determined from the aqua regia digestion leading to a slightly higher detection limit due to the greater dilution used in the aqua regia method. The H-3 concentration on a $\mathrm{Ci} /$ gal basis was calculated based on the density of the slurry.

The concentrations and detection limits reported are generally based on three or four replicate samples, though in a couple instances only a single value above the detection limit was measured. Concentrations of $\mathrm{H}-3$, Sr-90, and Pu-241 along with total beta activity are based on analyses by beta counting techniques. The concentrations of Co-60, Eu-154, Eu-155, and Am-241 were measured by Cs removed gamma counting. The concentration of Cs-137 was measured by gamma counting. The results for Tc-99, U-233, U-234, U-235, U-236, Np-237, U-238, Pu-239, and Pu-240, as well as Cm-245 following separation, were determined by Inductively Coupled Plasma Mass Spectroscopy (ICP-MS) that measures the concentration of these radionuclides based on their masses rather than their radioactivity. These concentrations were converted to $\mu \mathrm{Ci} / \mathrm{g}$ using their specific activities ${ }^{10}$. The results for $\mathrm{Pu}-238, \mathrm{Am}-242 \mathrm{~m}$, and Cm-244 along with the total alpha activity were measured by alpha counting. ${ }^{9}$ The concentrations of the following radionuclides: Ru-106, Rh-106, Sb-125, Te-125m, Cs-134, Ce-144, and Pr-144, are reported as method detection limits due to their concentrations being too low to be detected due to their short half-lives and/or the age of the sludge. The concentration of Cm-245 is also reported as method detection limits due to its low concentrations.

Both U-235 fission products, Pm-147 and Sm-151 were measured. The methodology used to obtain the concentration of the high-energy beta Pm-147 and lower-energy beta Sm-151 has been described previously $^{9}$. A detection limit for the Pm-147 is reported due to the low concentration in the aliquots measured.

The concentration reported for C-14 was calculated by DWPF/Saltstone Facility Engineering (DSFE) from the projected concentrations given in the Waste Characterization System (WCS) database for the C14 in the washed Tank 51 slurry prior to transferring it to Tank 40. This is the method that was agreed upon in the TTQAP for SB9 qualification. ${ }^{6}$

The radionuclide I-129 is a long-lived beta emitting fission product (half-life $\left(\mathrm{t}_{1 / 2}\right)=1.6 \mathrm{x} 10^{7}$ years) that is in Savannah River Site (SRS) wastes. Four aliquots of wet sludge slurry were prepared as described previously ${ }^{9}$ in the SRNL Shielded Cells, the Y-90 was allowed to decay for nine days, and the samples moved to $\mathrm{AD}$ for further preparation and analysis. 


\subsection{Quality Assurance}

Requirements for performing reviews of technical reports and the extent of review are established in manual E7 2.60. SRNL documents the extent and type of review using the SRNL Technical Report Design Checklist contained in WSRC-IM-2002-00011, Rev. 2.

\subsection{Results and Discussion}

Table 3-1 presents the measured or estimated concentrations for thirty seven individual radionuclides and the measured values for the total beta and total alpha activity along with the calculated values for total gamma and total beta plus gamma activities. Four radionuclides with measured values above their method detection limit, Sm-151, Eu-152, Th-232, and Cm-242, are included even though they were not explicitly called out in the TTR. ${ }^{5}$ The concentrations of those radionuclides that could not be measured due to their low concentrations have been estimated from minimum detection limits based on the analytical method used. For all the radionuclides except tritium $(\mathrm{H}-3)$, the concentrations are based on the total dried solids from dissolution of three or four replicates of the Tank 51 sludge slurry. Column 2 gives the concentration in units of wt\% total dried solids; Column 3 gives the concentrations in units of microcuries $(\mu \mathrm{Ci})$ per gram of total solids in the dried sludge slurry; Column 4 presents the relative percent standard deviations (\%RSD); and Column 5 presents the number of replicates analyzed. Finally, Column 6 presents the concentrations of the radionuclides in curies (Ci) per gallon of slurry calculated based on the measured weight percent total solids in the slurry (19.59 wt\%), the density of the slurry (1.15 $\mathrm{g} / \mathrm{mL}$ ), and a conversion factor of $3785 \mathrm{~mL} / \mathrm{gal}$ to convert to liquid gallons. Specific radionuclides will now be discussed.

Essentially all of the tritium in the Tank 51 slurry is present as tritiated water (HTO). Consequently, its concentration in the dried solids cannot be determined because the HTO evaporates during the drying of the slurry. The determination was made on aqua regia digestions prepared in sealed Teflon digestion vessels. The lowest detection limit for the supernate measurements was used to specify the concentration of $\mathrm{H}-3$.

The radionuclides Y-90, Rh-106, Te-125m, Ba-137m, and Pr-144 are in secular equilibrium with their respective parent radionuclides. Thus the activities of Y-90, Rh-106, Te-125m, and Pr-144 are equal to that of their parents. Approximately $5.4 \%$ of the Cs-137 decays directly to stable Ba-137; thus the activity of Ba- $137 \mathrm{~m}$ is $94.6 \%$ of the activity of the Cs-137.

The reported concentration of C-14 was not determined by proportioning the WCS projection to that measured for SB2 as was done prior to Sludge Batch (SB8). Instead, DSFE provided the value based on their calculations and the WCS projection. For comparison, the previous ratio method is based on the measured concentration of C-14 in SB2 of $8.13 \times 10^{-3} \mu \mathrm{Ci} / \mathrm{g} .{ }^{11}$ The projected concentration of C-14 in Sludge Batch (SB2) was $1.40 \times 10^{-6} \mathrm{Ci} /$ gallon. ${ }^{11}$ The WCS projection for the total curies of C-14 in Tank 51 when the slurry is ready to be transferred to Tank 40 is $8.20 \times 10^{-2}$ curies. ${ }^{12,13}$ The volume projected to be transferred to Tank 40 is $2.60 \times 10^{5}$ gallons slurry. ${ }^{12}$ The projected concentration of C-14 is then 3.15 $\times 10^{-7} \mathrm{Ci}$ /gallon slurry. Multiplying the ratio of the projected concentrations in Tank 51 to the projected concentrations in SB2 by the measured concentrations in SB2 gives $1.83 \times 10^{-3} \mu \mathrm{Ci} / \mathrm{g}$ for C-14, a value about $5 x$ larger than from the new estimation method.

The results for Tc-99 in the SB9 qualification sample are interesting in that they indicate that most of the Tc-99 that could have been in SB9 has been removed by the processing steps in the Canyons of SRS. As shown below, it is estimated that 91\% of the Tc-99 that could have been in SB9 has been removed to the salt tanks or volatilized as a result of SRS canyon processing. This estimate is determined by comparing the maximum amount of Tc-99 that can be predicted to be in SB9 with the measured amount. The 
measured concentration in the total dried solids of the SB9 slurry was $1.88 \times 10^{-3} \mathrm{wt} \%$ as determined by ICP-MS analysis. This concentration times the specific activity (SpA) of Tc-99 in Ci/g gives the activity concentration shown in Table 3-1.

The fission products in SB9 were formed in the SRS reactors by thermal neutron fission of U-235. Based on many experimental studies the relative yields of the fission products are known based on the number of atoms of each fission product isotope formed as a result of fission of 100 atoms of U-235. ${ }^{14}$ For a particular sludge batch, values for a fission yield scaling factor (FYSF) can be calculated from each measured concentration of a fission product. The FYSF is simply a proportionality factor that relates the concentration in wt\% of an isotope in the dried solids of sludge slurry to its fission yield and mass. For those isotopes that have six important properties, values for the FYSF will be equal for a sludge batch. These properties have been previously discussed. ${ }^{15}$ The following equation applies for each fission product.

$$
\mathrm{FYSF}_{\mathrm{i}}=\mathrm{wt} \%_{\mathrm{i}} /\left(\mathrm{FY}_{\mathrm{i}} \times \mathrm{am}_{\mathrm{i}}\right)
$$

Where $\mathrm{FYSF}_{\mathrm{i}} \equiv$ the fission yield scaling factor based on isotope $\mathrm{wt}_{\mathrm{t}} \mathrm{i}_{\mathrm{i}} \equiv$ the weight percent of isotope i in the High Level Waste (HLW) total dried solids $\mathrm{FY}_{\mathrm{i}} \equiv$ the fission yield of isotope $\mathrm{i}$ $\mathrm{am}_{\mathrm{i}} \equiv$ the atomic mass of isotope $\mathrm{i}$

In SB9 there are 11 fission products that have the six important properties. These isotopes are: Ru-101, Ru-102, Ru-103, La-139, Pr-141, Nd-143 through Nd-146, Sm-147, and Sm-148. All these isotopes were measured by ICP-MS in the total dried solids of the SB9 slurry. The average FYSF for SB9 calculated with these 11 isotopes is $3.35 \times 10^{-5}$ with a \%RSD of 11 . After rearrangement of the above equation, the concentration of any fission product can be predicted. For Tc-99 with its half-life of $2.13 \times 10^{5}$ years and fission yield of $6.1 \%$, the predicted wt $\%$ for Tc-99 is $2.02 \times 10^{-2} \mathrm{wt} \%$. The measured value is $1.88 \times 10^{-3}$ wt\%, indicating that only $9.3 \%$ of the Tc-99 that could have been in this sludge batch was actually still in the sludge slurry. One of the main properties that a fission product must have to be retained in the sludge solids is that it is insoluble in caustic. If it were soluble in caustic it would not precipitate in the sludge solids and would be decanted or washed to the salt tanks in the Tank Farm. Technetium is known to form a pertechnetate anion that is soluble in caustic. ${ }^{15}$ This can explain the low concentration of Tc-99 in SB9 and was also previously observed for Sludge Batch (SB3) ${ }^{15}$ and SB6 ${ }^{16}$.

The radionuclide I-129 is a U-235 fission product with a long half-life of $1.6 \times 10^{7}$ years. It was first measured successfully in the SB4 Waste Acceptance Product Specifications (WAPS) studies ${ }^{9}$ and the Sludge Batch (SB5) Acceptance Evaluation. ${ }^{17}$ Earlier reported concentrations for sludge batches are based on the WCS database. For I-129 the average measured from four aliquots of the sludge slurry was $5.31 \times 10^{-3} \mathrm{\mu Ci} / \mathrm{g}$ of total dried solids or $3.01 \times 10^{-3} \mathrm{wt} \%$. Based on the separations and counting results, this appears to be a reliable result. However, it was further checked by calculating the amount of I-129 that could be present using the FYSF. If this predicted concentration were less than the measured concentration, this would indicate that the measured number was erroneously high. Using the FYSF of $3.35 \times 10^{-5}$ and the fission yield for I-129 of $0.54 \%,{ }^{14}$ the predicted concentration of I-129 in SB9 would be $2.3 \times 10^{-3} \mathrm{wt} \%$, assuming no I-129 were lost in processing. The measured value is about $30 \%$ higher. If the International Atomic Energy Agency (IAEA) fission yield for I-129 of $0.706 \%$ is used, ${ }^{18}$ the predicted concentration of I-129 in SB9 would be $3.05 \times 10^{-3} \mathrm{wt} \%$, which is what was measured. Iodine is expected to be retained in HM sludges due to the mercuric nitrate catalyst, which results in nonvolatile mercury species. ${ }^{19}$ 
Table 3-1. Concentrations of Radionuclides in the Tank 51 SB9 Qualification Sample

\begin{tabular}{|c|c|c|c|c|c|}
\hline Radionuclide & $\begin{array}{l}\text { Wt\% in Total } \\
\text { Dried Solids }\end{array}$ & $\begin{array}{c}\mu \mathrm{Ci} / \mathrm{g} \text { in Total } \\
\text { Dried Solids }\end{array}$ & $\%$ RSD & Replicates & $\begin{array}{l}\text { Ci/gal in Sludge } \\
\text { Slurry (a) }\end{array}$ \\
\hline H-3 & (b) & (b) & N/A & N/A & $<3.5 \mathrm{E}-05$ \\
\hline C-14 (c) & 8.64E-09 & 3.85E-04 & N/A & N/A & $3.28 \mathrm{E}-07$ \\
\hline Co-60 & 2.85E-08 & 3.23E-01 & 1.1 & 3 & $2.75 E-04$ \\
\hline Sr-90 & 3.34E-03 & $4.56 \mathrm{E}+03$ & 8.0 & 3 & $3.89 \mathrm{E}+00$ \\
\hline Y-90 & 3.34E-03 & $4.56 \mathrm{E}+03$ & 8.0 & 3 & $3.89 E+00$ \\
\hline Тc-99 & $1.88 \mathrm{E}-03$ & 3.19E-01 & 1.6 & 3 & 2.72E-04 \\
\hline Ru-106 & $<3.7 \mathrm{E}-09$ & $<1.2 \mathrm{E}-01$ & N/A & N/A & $<1.1 \mathrm{E}-04$ \\
\hline Rh-106 & $<3.5 E-15$ & $<1.2 \mathrm{E}-01$ & N/A & N/A & $<1.1 \mathrm{E}-04$ \\
\hline Sb-125 & $<4.9 \mathrm{E}-09$ & $<5.1 \mathrm{E}-02$ & N/A & N/A & $<4.3 \mathrm{E}-05$ \\
\hline Te-125m & $<2.8 \mathrm{E}-10$ & $<5.1 \mathrm{E}-02$ & N/A & N/A & $<4.3 \mathrm{E}-05$ \\
\hline $\mathrm{I}-129$ & 3.01E-03 & 5.31E-03 & 8.3 & 4 & $4.52 \mathrm{E}-06$ \\
\hline Cs-134 & $<2.4 \mathrm{E}-08$ & $<3.1 \mathrm{E}-01$ & N/A & N/A & $<2.6 \mathrm{E}-04$ \\
\hline Cs-137 & 1.30E-03 & $1.13 \mathrm{E}+03$ & 2.9 & 3 & $9.64 \mathrm{E}-01$ \\
\hline Ва-137m & $1.99 \mathrm{E}-10$ & $1.07 \mathrm{E}+03$ & 2.9 & 3 & 9.12E-01 \\
\hline Ce-144 & $<1.2 \mathrm{E}-08$ & $<3.7 \mathrm{E}-01$ & N/A & N/A & $<3.1 \mathrm{E}-04$ \\
\hline Pr-144 & $<4.8 \mathrm{E}-13$ & $<3.7 \mathrm{E}-01$ & N/A & N/A & $<3.1 \mathrm{E}-04$ \\
\hline Pm-147 & $<6.4 \mathrm{E}-06$ & $<5.9 \mathrm{E}+01$ & N/A & N/A & $<5.1 \mathrm{E}-02$ \\
\hline Sm-151 & $3.29 \mathrm{E}-04$ & $8.65 E+01$ & 5.1 & 3 & 7.37E-02 \\
\hline Eu-152 & 5.09E-08 & 8.81E-02 & 12 & 3 & 7.51E-05 \\
\hline Eu-154 & 1.79E-06 & $4.84 \mathrm{E}+00$ & 6.5 & 3 & 4.13E-03 \\
\hline Eu-155 & $1.45 \mathrm{E}-07$ & 6.74E-01 & 35 & 3 & 5.75E-04 \\
\hline Th-232 & 8.01E-01 & 8.79E-04 & 0.73 & 4 & $7.50 \mathrm{E}-07$ \\
\hline U-233 & 7.67E-04 & 7.43E-02 & 2.6 & 4 & 6.33E-05 \\
\hline U-234 & 8.57E-04 & 5.36E-02 & 3.7 & 4 & 4.57E-05 \\
\hline U-235 & 4.45E-02 & 9.62E-04 & 1.3 & 4 & $8.20 \mathrm{E}-07$ \\
\hline U-236 & 2.35E-03 & $1.52 \mathrm{E}-03$ & 0.67 & 4 & 1.30E-06 \\
\hline Np-237 & 2.92E-03 & 2.06E-02 & 1.2 & 4 & 1.75E-05 \\
\hline U-238 & $3.05 E+00$ & $1.02 \mathrm{E}-02$ & 1.2 & 4 & 8.73E-06 \\
\hline $\mathrm{Pu}-238$ & 7.97E-04 & $1.36 \mathrm{E}+02$ & 17 & 3 & $1.16 \mathrm{E}-01$ \\
\hline Pu-239 & $6.78 \mathrm{E}-03$ & $4.21 \mathrm{E}+00$ & 1.4 & 4 & 3.59E-03 \\
\hline $\mathrm{Pu}-240$ & 7.03E-04 & $1.60 \mathrm{E}+00$ & 1.2 & 4 & $1.37 \mathrm{E}-03$ \\
\hline $\mathrm{Pu}-241$ & 3.02E-05 & $3.11 \mathrm{E}+01$ & 18 & 3 & 2.65E-02 \\
\hline Am-241 & 3.39E-04 & $1.16 \mathrm{E}+01$ & 4.2 & 3 & $9.92 \mathrm{E}-03$ \\
\hline Am-242m & 1.97E-05 & $1.91 \mathrm{E}+00$ & N/A & 1 & 1.63E-03 \\
\hline $\mathrm{Cm}-242$ & 4.79E-08 & $1.58 \mathrm{E}+00$ & N/A & 1 & 1.35E-03 \\
\hline $\mathrm{Cm}-244$ & 5.02E-06 & $4.06 \mathrm{E}+00$ & 10 & 3 & $3.46 \mathrm{E}-03$ \\
\hline Cm-245 & $<3.0 \mathrm{E}-07$ & $<5.1 \mathrm{E}-04$ & N/A & N/A & $<4.4 \mathrm{E}-07$ \\
\hline Total alpha & N/A & $1.97 \mathrm{E}+02$ & 1.4 & 3 & $1.68 \mathrm{E}-01$ \\
\hline Total beta & N/A & $1.18 \mathrm{E}+04$ & 1.6 & 3 & $1.00 \mathrm{E}+01$ \\
\hline Total gamma(d) & N/A & $1.09 \mathrm{E}+03$ & N/A & N/A & $9.26 \mathrm{E}-01$ \\
\hline Total beta-gamma & N/A & $1.29 E+04$ & N/A & N/A & $1.10 \mathrm{E}+01$ \\
\hline
\end{tabular}

$\mathrm{N} / \mathrm{A} \equiv$ not applicable.

(a) This was calculated for all the radionuclides except H-3 using the weight percent total solids in the slurry of 19.59 and a slurry density of 1.15 $\mathrm{g} / \mathrm{mL}$.

(b) Most of the H-3 in the slurry is present as HTO; thus, drying the slurry sample would drive off most of the H-3. The concentration of H-3 was measured in four slurry samples. The result was $<8.04 \mathrm{E}-03 \mu \mathrm{Ci} / \mathrm{g}$ slurry. This was converted to Ci/gal slurry using slurry density.

(c) Calculated value. ${ }^{12}$

(d) The total activity of the gamma emitters: Co-60, Ru-106, Rh-106, Sb-125, Te-125m, Cs-134, Ba-137m, Ce-144, Pr-144, Eu-152, Eu-154, Eu155, and Am-241. 
Table 3-2 provides the replicate measurements made for the fissile radionuclides in order for DWPF to ensure the fissile content of the glass in a canister is below the $897 \mathrm{~g} / \mathrm{m}^{3}$ DOE requirement. ${ }^{5}$

Table 3-2 Replicate Activities of Fissile Radionuclides for the SB9 Qualification Sample in $\mu \mathrm{Ci} / \mathrm{g}$ of Total Dried Solids*

\begin{tabular}{ccccccc}
\hline Radionuclide & Repl. 1 & Repl. 2 & Repl. $\mathbf{3}$ & Repl. 4 & Reported & \%RSD** $^{*}$ \\
\hline U-233 & $7.51 \mathrm{E}-02$ & $7.40 \mathrm{E}-02$ & $7.63 \mathrm{E}-02$ & $7.17 \mathrm{E}-02$ & $7.43 \mathrm{E}-02$ & 2.6 \\
U-235 & $9.59 \mathrm{E}-04$ & $9.59 \mathrm{E}-04$ & $9.49 \mathrm{E}-04$ & $9.78 \mathrm{E}-04$ & $9.62 \mathrm{E}-04$ & 1.3 \\
Pu-239 & $4.14 \mathrm{E}+00$ & $4.24 \mathrm{E}+00$ & $4.20 \mathrm{E}+00$ & $4.28 \mathrm{E}+00$ & $4.21 \mathrm{E}+00$ & 1.4 \\
Pu-241 & $2.53 \mathrm{E}+01$ & $3.15 \mathrm{E}+01$ & $3.66 \mathrm{E}+01$ & N/A & $3.11 \mathrm{E}+01$ & 18 \\
\hline
\end{tabular}

* ICP-MS data unless specified otherwise

${ }^{\ddagger} \mathrm{Pu}-238 /-241$ method.

**Values in the \%RSD column are relative to the true calculated averages of the quantities in the table, while the average values reported have been rounded off to a reasonable number of significant figures.

\subsection{Conclusions}

The results presented in this report are those necessary for DWPF to assess if SB9 meets the requirements for the DWPF Radiological Program Evaluation, the DWPF WAC evaluation, and the DWPF Solid Waste Characterization Program. Concentrations are given for thirty-seven radionuclides along with total alpha and beta activity. Values for total gamma and total gamma plus beta activities are also calculated.

Results also indicate that $91 \%$ of the Tc-99 that could have been in this sludge batch was removed by chemical processing steps in the SRS Canyons or Tank Farm - it is typical for Tc-99 to partition to the salt phase of the waste. The I-129 found in the sludge was likely retained as a nonvolatile mercury species.

\subsection{References}

1. Pareizs, J. M.; Crawford, C. L. Sludge Washing and Demonstration of the DWPF Flowsheet in the SRNL Shielded Cells for Sludge Batch 8 Qualification, SRNL-STI-2013-00116, Savannah River National Laboratory, Aiken, SC 29808 (2013).

2. Pareizs, J. M. Characterization of the As-Received Sludge Batch 9 Qualification Sample (HTF-51-1581), SRNL-STI-2015-00442, Savannah River National Laboratory, Aiken, SC 29808 (2015).

3. Gillam, J. M. Sludge Batch 9 Washing Spreadsheet: SB9_102015.xlsm, Savannah River Remediation, Aiken, SC 29808 (2015).

4. Pareizs, J. M. Characterization of the SRNL-Washed Tank 51 Sludge Batch 9 Qualification Sample, SRNL-STI-2015-00693, Savannah River National Laboratory, Aiken, SC 29808 (2016).

5. Samadi-Dezfouli, A. Technical Task Request: Sludge Batch 9 Qualification, Confirmatory, and Waste Acceptance Product Specification Samples, U-TTR-S-00009, Rev. 1, Savannah River Site, Aiken, SC 29808 (2015). 
6. Pareizs, J. M. Task Technical and Quality Assurance Plan for Sludge Batch 9 Qualification, Confirmatory, and Waste Acceptance Product Specification Samples, SRNL-RP-2015-00120, Rev. 1, Savannah River National Laboratory, Aiken, SC 29808 (2015).

7. Coleman, C. J. Alkali Fusion Dissolutions of Sludge and Glass for Elemental Analysis, Manual L16.1, Procedure ADS-2502, Rev. 7, Savannah River National Laboratory, Aiken, SC 29808 (2013).

8. Coleman, C. J. Aqua Regia Dissolution of Sludge for Elemental Analysis, Manual L16.1, Procedure ADS-2226, Rev. 10, Savannah River National Laboratory, Aiken, SC 29808 (2013).

9. Bannochie, C. J.; DiPrete, D. P. Determination of Reportable Radionuclides for DWPF Sludge Batch 8 (Macrobatch 10), SRNL-STI-2014-00179, Savannah River National Laboratory, Aiken, SC 29808 (2014).

10. Integrated Data Base Report - 1996: U.S. Spent Nuclear Fuel and Radioactive Waste Inventories, Projections, and Characteristics, DOE/RW-0006, Rev. 13, Oak Ridge National Laboratory, Oak Ridge, TN (1997).

11. Bibler, N. E.; DiPrete, D. P.; Harbour, J. R. Determination of Reportable Radionuclides for DWPF Sludge Batch 2 (Macro Batch 3) (U), WSRC-TR-2002-00255, Savannah River Site, Aiken, SC 29808 (2002).

12. Brotherton, K. M. Estimated Activity Concentration of C-14 in Sludge Batch 9 Solids, X-CLC-S00348, Savannah River Site, Aiken, SC 29808 (2016).

13. Reboul, S. H. Expedited Analysis of Tank 51 Alternate Reductant Sludge Batch 9 Sample (HTF-5115-130), SRNL-L3100-2016-00003, Savannah River National Laboratory, Aiken, SC 29808 (2016).

14. Baum, E. M.; Knox, H. D.; Miller, T. R. Nuclides and Isotopes (Chart of the Nuclides), $16^{\text {th }}$ Edition, KAPL, Inc. and Lockheed Martin, 2002.

15. Bibler, N. E.; Fellinger, T. L.; Hobbs, D. T. Technetium-99 Behavior in Savannah River Site HLW Sludges During Waste Processing, WSRC-MS-2004-00614, Savannah River Site, Published as Paper No. 4 in Session 43 of WM'06 Proceedings, WM Symposium, Tucson, AZ, February 2006.

16. Bannochie, C. J.; Bibler, N. E.; DiPrete, D. P. Sludge Batch 6 Acceptance Evaluation: Radionuclide Concentrations in Tank 51 SB6 Qualification Sample Prepared at SRNL, SRNL-STI-2010-00180, Rev. 1, Savannah River National Laboratory, Aiken, SC 29808 (2010).

17. Bannochie, C. J.; Bibler, N. E.; DiPrete, D. P. Sludge Batch 5 Acceptance Evaluation: Radionuclide Concentrations in Tank 51 SB5 Qualification Sample Prepared at SRNL, WSRC-STI-2008-00352, Rev. 1, Savannah River Site, Aiken, SC (2008).

18. Nichols, A. L.; Aldama, D. L.; Verpelli, M. Handbook of Nuclear Data for Safeguards: Database Extensions, August 2008; IAEA Nuclear Data Section: Vienna, Austria, 2008; pp 78. 
19. Kantelo, M. V.; Bauer, L. R.; Marter, W. L.; Murphy, Jr., C. E.; Zeigler, C. C. Radioiodine in the Savannah River Site Environment, WSRC-RP-90-424-2, Savannah River Site, Aiken, SC 29808 (1992). 


\section{Distribution:}

\begin{tabular}{|c|c|c|c|}
\hline C. I. & Aponte & S. H. & Reboul \\
\hline M. J. & Barnes & & Records Administration (EDWS) \\
\hline H. P. & Boyd & M. A. & Rios-Armstrong \\
\hline E. A. & Brass & P. J. & Ryan \\
\hline J. M. & Bricker & A. & Samadi-Dezfouli \\
\hline M. A. & Broome & A. R. & Shafer \\
\hline T. B. & Brown & H. B. & Shah \\
\hline M. E. & Cercy & D. C. & Sherburne \\
\hline M. C. & Clark & C. G. & Sherer \\
\hline J. S. & Contardi & M. E. & Smith \\
\hline C. L. & Crawford & G. N. & Smoland \\
\hline $\mathrm{J}$. & Crenshaw & D. E. & Snyder \\
\hline D. A. & Crowley & M. E. & Stone \\
\hline D. P. & DiPrete & C. B. & Sudduth \\
\hline D. E. & Dooley & R. D. & Thames \\
\hline T. B. & Edwards & J. R. & Vitali \\
\hline R. E. & Edwards, Jr. & A. L. & Washington \\
\hline A. P. & Fellinger & A. W. & Wiggins \\
\hline T. L. & Fellinger & W. R. & Wilmarth \\
\hline S. D. & Fink & R. H. & Young \\
\hline E. J. & Freed & & \\
\hline J. M. & Gillam & & \\
\hline B. A. & Hamm & & \\
\hline C. C. & Herman & & \\
\hline D. T. & Hobbs & & \\
\hline E. N. & Hoffman & & \\
\hline E. W. & Holtzscheiter & & \\
\hline J. E. & Hyatt & & \\
\hline J. F. & Iaukea & & \\
\hline P. & Jackson & & \\
\hline V. & Jain & & \\
\hline F. C. & Johnson & & \\
\hline K. M. & Kostelnik & & \\
\hline D. P. & Lambert & & \\
\hline B. B. & Looney & & \\
\hline C. J. & Martino & & \\
\hline D. A. & McGuire & & \\
\hline R. T. & McNew & & \\
\hline T. O. & Oliver & & \\
\hline J. M. & Pareizs & & \\
\hline F. M. & Pennebaker & & \\
\hline J. W. & Ray & & \\
\hline
\end{tabular}

